\title{
Residual Cancer Burden
}

National Cancer Institute

\section{Source}

National Cancer Institute. Residual Cancer Burden. NCI Thesaurus. Code C160722.

An indication of the amount of invasive cancer in breast or lymph node tissue after completion of neoadjuvant chemotherapy. 